16. Iavornytskyi, D. I. (1991). Istoriia zaporozkykh kozakiv [History of Zaporozhye Cossacks]. U 3 tomakh. T. II. Lviv: Svit.

17. Serczyk, W. (1998). Na plonącej Ukrainie. Dzieje Kozaczyzny 1648-1651 [In the burning Ukraine. History of the Cossacks 1648-1651]. Warszawa: «Książka i Wiedza».

18. Franz, M. (2002). Wojskowośc Kozaczyzny Zaporoskiej w XVI-XVII wieku [The military of the Zaporizhian Cossacks in the 16th and 17th centuries]. Torun: Wydawnictwo Adam Marszałek.

19. Franz, M. (2006). Idea państwa kozackiego na ziemiach ukrainnych w XVI-XVII wieku [The idea of a Cossack state in the Ukrainian lands in the 16th-17th centuries]. Toruń: Wydawnictwo Adam Marszałek.

20. Wójcik, Z. (1989). Wojny kozackie w dawnej Polsce [Cossack wars in former Poland]. Kraków: Agencja Wydawnicza DWWLA.

УДК 929.7 (477) «18»

\title{
М. ГОЛУБЕЦЬ: ПОГЛЯДИ НА ПОЛІТИЧНУ ІСТОРІЮ ГЕТЬМАНЩИНИ ХVIII СТ.
}

\section{Людмила Салагуб}

У статті розглянуто погляди украӥнського історика М. Голубия щзодо політичного становища Гетьманщини XVIII cm.; окреслено питання, пов'язані з діяльністю політичних інституиій на украӥнських теренах, взаємовідносинами украӥнських гетьманів з представниками російського царату. Дослідження базується на принципах історизму, наукової об'єктивності, соціального підходу та причинності. Воно спирається на описовий, аналітико-синтетичний та історико-генетичний методи. Результатом дослідницької наукової роботи є характеристика політичного розвитку Гетьманщини протягом XVIII cm. через призму поглядів М. Голубия, обтрунтування обставин, які стали каталізатором для формування його концепції висвітлення тогочасної історичної «картини».

Результати иієё розвідки можуть стати в нагоді науковиям-початківиям під час дослідження окремих аспектів політичної історії Гетьманщини XVIII cm., у прочесі викладання спецкурсів, присвячених подіям, що відбувалися в Украӥни в межах 1709-1764 рр. Перспективи подальшого дослідження проблеми полягають у залученні ширшого кола прачь істориків, науково-дослідницька діяльність яких проходила на теренах Західної Украӥни в першій половині XX cm., порівнянні їхніх поглядів на подї в історії Гетьманщини XVIII cm. та визначенні факторів, щчо вплинули на їхне формування. Цінність розвідки - у висвітленні концепиії М. Голубия щчодо політичного становища Гетьманщчини XVIII cm.

Ключові слова: М. Голубець, історія Гетьманщини, автономні права, Малоросійська Колегія.

Зі здобуттям незалежності України для вітчизняних істориків відкрилося багато нових можливостей, яких за радянських часів вони не мали. Зокрема: доступ до архівних документальних джерел, які раніше були засекречені, можливість вільно долучатися до здобутків західноєвропейської історичної думки тощо. Історія Гетьманщини XVIII ст. є однією з найбільш цікавих і водночас суперечливих. Дослідження iї проб- 
лематики пройшло кілька етапів. Зокрема: дореволюційний (XIX - поч. 20-х pp. XX ст.); радянський (поч. 20-х pp. XX ст. - 1991 р.) та сучасний (розпочався в 1991 р. і триває донині). До вивчення історії Гетьманщини долучилися такі видатні корифеї історичної науки: Д. М. Бантиш-Каменський, М. А. Маркевич, М. С. Грушевський, О. Я. Сфименко.

Серед українських істориків, активна діяльність яких припадає на 20-ті - поч. 30-х рр. ХХ ст., знаковою постаттю є М. Голубець - автор праці «Велика історія України». Стислі біографічні відомості про нього здебільшого містяться у статтях Р. Я. Савицького [8], I. І. Сварника [9], Я. Гнатіва [2], І. Головацького [3], Г. П. Герасимової [1]. В. А. Качкан висвітлює погляди М. Голубця через призму етнокультурного, українознавчого поля $[5,6]$. Його діяльність у контексті мистецького процесу міститься у статті Т. Стефанишина [11]. Не зважаючи на це, публікацій, які б висвітлювали діяльність та науковий доробок М. Голубця як історика, бракує. Винятком є статті I. I. Сварника «Українська шляхта в дослідженнях Миколи Голубця» [10] та Л. Кічури «Ідея державності в публіцистиці Миколи Голубця (за матеріалами преси)» [7]. Жодна розвідка не присвячена окресленню концепту поглядів М. Голубця на події XVIII ст., що відбувалися на теренах Гетьманщини. Ця обставина й зумовила визначення проблематики дослідження. Мета статті полягає в характеристиці поглядів західноукраїнського історика Миколи Голубця на політичну історію Гетьманщини XVIII ст. та виявлення факторів, що зумовили їхнє формування.

У 1920-ті рр. доволі драматично склалася доля українців західних регіонів, які опинилися у складі різних держав. Не зважаючи на антиукраїнську політику, особливо польського та румунського режимів, ліквідацію українських кафедр у Львівському і Чернівецькому університетах, продовжувалося дослідження української історії. Через освітні заклади, політичні партії, громадські об’єднання «Просвіта», «Союз українок», «Рідна школа», «Пласт» поширювалися історичні знання серед населення. У Львові діяли Український таємний університет, Українська таємна висока політехнічна школа, Богословська академія. Лекції з історії у них читали І. Крип'якевич, I. Кревецький та ін. Продовжувало свою діяльність Наукове товариство імені Шевченка, яке утримувало бібліотеку, три музеї, два дослідницькі інститути. На спрямованість наукових досліджень істориків та історичну свідомість населення Західної України помітний вплив справляли праці ідеологів українського націоналізму, зокрема Д. Донцова.

Після встановлення радянської влади на території Західної України почав придушуватися плюралізм думок, який до цього там переважав. Так звані соціалістичні перетворення, радянізація краю торкнулися історичної науки, українознавчих осередків, системи освіти, зокрема Львівського та Чернівецького університетів, НТШ, товариств «Просвіта», «Україна». Діяльність останніх була припинена. Тож за умов, коли українська історіографія в УСРР припинила існування як явище, єдиними острівцями iii розвитку залишалася Західна Україна, а також українська діаспора в Центральній і Західній Європі, Канаді та США. У 1935 р. у Львові І. Тиктор видав «Велику історію України» за редакцією М. Голубця - українського історика, письменника, мистецтвознавця, архівіста, перекладача. 
М. Голубець народився 15 грудня 1891 р. у м. Львові. Закінчив Львівську академічну гімназію та Академію мистецтв у м. Кракові. Навчався на філософському факультеті Львівського університету та у Віденському університеті. Протягом Першої світової війни був добровольцем Легіону Українських січових стрільців. Мав ранг підхорунжого. Наприкінці 1918 р. став командиром чоти Української Галицької армії, брав участь у бойових діях українсько-польської війни 1918-1919 pр. М. Голубець був першим чоловіком сестри М. Бачинської-Донцової - Лесі Бачинської, яка після його смерті одружилася з С. М. Підгірським - адвокатом, політиком, українським громадським активістом, членом двох скликань Української Центральної Ради та двох скликань Польського Сейму. Лесю, їхню з М. Голубцем доньку, Нану, та їі чоловіка розстріляло гестапо за зв'язок з УПА.

На початку 1920-х рр. М. Голубець активно долучився до наукової, літературної та культурологічної діяльності. Був членом комісії Наукового товариства імені Шевченка у м. Львові з історії мистецтва, одним із організаторів Асоціації незалежних українських митців. Після вересня 1936 р. працював у Львівському міському архіві. Протягом німецької окупації Львова заснував Літературно-мистецький клуб, працював над тритомною історією української культури. Як дослідник історії українського мистецтва та історії України, Львова та регіону написав 84 книги та брошури, понад 1500 статей. Він є автором низки брошур і статей про таких українських митців: О. Архипенко, Т. Шевченко, Ю. Нарбут, О. Кульчицька та ін. М. Голубець видавець та редактор 14 тижневиків і щоденних газет, зокрема: «Світ» (1917-1918рр.), «Життя і мистецтво» (1920р.), «Українське мистецтво» (1926 р.) тощо. Художню творчість М. Голубець почав як поет збіркою віршів «Фрагменти» (1909 р.) та «Бувають хвилі» (1910р.). Він $є$ автором таких праць: «Слідами Хмельницького у Львові», «Українське мистецтво: Вступ до історії», «Начерк історії українського мистецтва» та ін. Із-поміж них одне з чільних місць посідає праця «Велика історія України» [4]. Двотомник охоплює величезний період історії українського народу - від найдавніших часів до 1935 р. Автором вступу є І. Крип'якевич - відомий радянський та український історик, академік Академії наук УРСР, заслужений діяч науки УРСР. Другий том «Великої історії України» охоплює виклад історії України з XVI ст. до 1935 р. У XXVII-XXVIII розділах праці висвітлені питання політичної історії Гетьманщини XVIII ст., що надає можливість проаналізувати ключові особливості тогочасних політичних перипетій на теренах Лівобережної України.

Висвітлення політичної історії Гетьманщини XVIII ст. у праці М. Голубця «Велика історія України» докорінно відрізняється від представленого радянськими істориками. Він не вважає вчинок гетьмана І. Мазепи зрадницьким, засуджує діяльність Малоросійської колегії, із великою шаною ставиться до українських гетьманів та їхньої діяльності, спрямованої на боротьбу за залишки автономних прав України. Автор так описує становище, в якому опинилася Україна на початку XVIII ст.: «Полтавський розгром і польсько-московсько-турецьке перемир'я, на довгі десятиліття закріпили розвал українського державного організму. Київщина, Волинь і Поділля залишилися під Польщею, Лівобережжя загорнула Московщина, на півдні панували 
турки, а господарили татари. Тут, при Дніпровому гирлі, в Олешках, створили прихильні Мазепі запоріжці нову Січ, що втративши зв'язок з рідним краєм, перемінилися в своєрідний табор інтернованих» [4, 119]. М. Голубець пояснює, що гетьманом після I. Мазепи був обраний І. Скоропадський. Автор схиляється до того, що спочатку він був однодумцем І. Мазепи, а після подій 1709 р. почав удавати прихильне ставлення до царя $[4,120]$. Окрім того, він акцентує увагу на обмеженні влади українського гетьмана, повідомляючи про стольника Ізмайлова, який повинен був слідкувати за діями гетьмана, розпоряджатися двома московськими полками тощо [4, 121].

У праці простежується негативне ставлення М. Голубця до Петра I. Із ним автор пов'язує процес ліквідації автономних прав України. Акцентовано увагу на використанні українського козацтва у військових кампаніях, на будівництві різних каналів: «Вслід за «канальними роботами» почав цар Петро висилати козаків на війну з Персією, що почалася в 1721 р. Трицять тисяч з горою козаків післано на перський фронт протягом найблищих трьох літ. 36800 козаків, що в 1725 р. стояли під Дербентом, згинуло в боях та від пошестей 5 200! Тільки 646 козаків залишилося при здоровлю. Решту відіслано інвалідами до дому. Отак цар Петро прибирав до рук Україну» [4, 122].

На відміну від радянських істориків, які недооцінювали діяльність українських гетьманів щодо захисту автономних прав України, М. Голубець закцентував увагу на діяльності гетьмана I. Скоропадського. На його думку, політичні кроки українського керманича рятували залишки автономних прав Гетьманщини, викликаючи недовіру російського царя Петра I $[4,122]$. Виразно та цікаво автор характеризує причини створення Малоросійської колегії у 1722 р.: «Петро, що вмів приємно усміхатися, гладити словами, а нищити ділом, додумався врешті до того, що для забезпечення себе перед «зрадою» замало при гетьмані одного шпіона-провокатора. Для цього поставив він біля нього цілу їх шайку й назвав цю установу «Малоросійською Колєгією»»» [4, 122].

Після смерті І. Скоропадського наказним гетьманом України став П. Полуботок, який виступив проти дій царя Петра I та Малоросійської колегії щодо Гетьманщини. Більшість радянських істориків повідомляли про скарги населення на гетьмана і старшину, які подавалися до Малоросійської колегії, як правдиві. Натомість, М. Голубець відстоює іншу точку зору: «Царські агенти вислані на Україну для збирання жалоб на козацьку старшину, суди й адміністрацію, здебільша вертали з нічим. Заяви льояльности цареві й прозьби про заведення московських судів та порядків, як приміром від стародубського полку, фабрикувалися в канцелярії Велямінова й навіть царя не переконували» $[4,124]$.

1727 р. скасовано Малоросійську колегію і дозволено обрати нового гетьмана. Козацькою старшиною і представниками духовенства було «намічено» кандидатуру Данила Апостола. Саме його обрали гетьманом на Великій Раді 1 жовтня 1727 p. М. Голубець із неабияким «мовним забарвленням» характеризує російських високопосадовців, яких царат призначав до українських керманичів із метою обмеження їхніх прав, звуження можливостей реалізувати свій політичний вектор на теренах Гетьманщини. Зокрема, про Ф. Наумова знаходимо такі відомості: «... залишився при гетьмані, зразу як міністр-резидент, а відтак як тайний радник - випробуване вже 
«царське око й ухо» $[4,125]$. М. Голубець стверджує: «Все ж таки Апостол, за протяг свого шестилітнього гетьманування, добре заслужився Україні, а вміраючи 17 січня 1734 р. залишав по собі жаль і добру пам'ять серед народу» [4, 127]. Смерть Д. Апостола була смертю й української автономії. Помираючи, він бажав передати владу генеральній старшині, але російський царат цього не дозволив. Від хворого гетьмана перейняв владу царський резидент Наришкін, а як тільки Д. Апостол помер, у Петербурзі вирішили не обирати нового гетьмана. Його місце мала зайняти знову «Малоросійська Колєгія», хоч і під новим іменем - «Правління Гетьманського Уряду». Окрім жорсткого режиму, на Україну «впав» ще й тягар московсько-турецької війни, що почалася в 1735 р. М. Голубець повідомляє: «Вже на самому початку невдачної, турецької кампанії в 1735 р. гетьманське військо втратило 12 000, заморених голодом, коней. У черговому році набрано 16000 гетьманського війська та 4000 запоріжців, при яких допомозі здобули москалі ханську столицю Бахчисарай» [4, 129].

М. Голубець зазначає, що за часів правління К. Розумовського справи України було переведено з сенату до міністерства закордонних справ, він теж подбав про підпорядкування Києва й Запоріжжя безпосередньо гетьманській владі, проте не міг відборонитися від московського контролю над українськими фінансами, врятувати для гетьманського скарбу приходів з мита від ввозу й вивозу з України, добитися права вільних зв'язків з чужоземними державами, як теж визволити України від обов'язків і тягарів, що падали на неї з приводу воєн поза межами України [4, 131].

Смерть цариці Єлизавети (1761р.), коротке панування Петра III й палатна революція на користь його дружини, німецької княжни Катерини II, позначилися дуже болюче в історії України. Катерина II, пройнята ідеями централізації російської імперії, поклала свою тяжку руку на автономні права України. Доречним є включення до праці висловлювання Т. Г. Шевченка, мовляв «це той Первий, що розпинав ненькуУкраїну, а Вторая доконала вдову-сиротину...» [4, 131]. Окрім висвітлення політичного розвитку Гетьманщини впродовж 1709-1754 pp., М. Голубець повідомляє також про розвиток Запоріжжя в цей період: «Вік Запоріжжя, як автономної одиниці в лоні Гетьманщини, від його повороту під московську руку в 1734-1735 рр. був уже недовгий $[4,133]$. Автор надає відомості, ознайомившись із якими можна дізнатися, що населення Гетьманщини часто переходило на терени Запоріжжя. Причина - панщина на Правобережжі та закріпачення в Гетьманщині $[4,133]$.

Отже, виклад політичної історії Гетьманщини у праці українського історика М. Голубця «Велика історія України» докорінно відрізняється від панівної в ті часи «радянської концепції». На відміну від науковців, які займалися дослідженнями на теренах СРСР, історики західної України сприйняли концепцію історії України М. Грушевського, зокрема висвітлення політичної історії Гетьманщини. Підходи М. Голубця до вивчення політичної історії Гетьманщини подібні до поглядів українських істориків у західній діаспорі. Відзначимо також, що для стилю викладення цієї роботи характерна певна публіцистичність, загостреність характеристик, що демонструють відверте неприйняття автором україно-російського союзу як варіанта розвитку України. 
Перспективи подальшого дослідження проблеми полягають у залученні ширшого кола праць істориків, науково-дослідницька діяльність яких проходила на теренах Західної України в першій половині XX ст., порівнянні їхніх концепцій висвітлення історії Гетьманщини упродовж XVIII ст. та визначенні факторів, що вплинули на їхнє формування.

\title{
Summary
}

The Ukrainian historian N. Holubets's views on the political situation of the Hetmanate of the XVIII ${ }^{\text {th }}$ century have been considered in the article; the issues depicting political institutions activity on the territory of Ukraine, Ukrainian hetmans relationship with Russian tsarism representatives have been stated. The study is based on the principles of historical methods, scientific objectivity, social approach and causality. It is based on descriptive, analytical-synthetic and historical-genetic methods. The result of the research work is to characterize the Hetmanate political development of the XVIII ${ }^{\text {th }}$ century through M. Holubets views prism, to justify the circumstances which helped him to form his conception of that time historical situation.

The results of this work can help scientists-beginners to research certain aspects of the Hetmanate political history of the XVIII th century while teaching special courses on the events that took place in Ukraine from 1709 till 1764. Prospects for further study of the problem are to attract a wider range of works of historians, research activities which took place on the territory of Western Ukraine in the first half of the twentieth century, comparing their views on the events in the history of Hetmanate of the XVIII ${ }^{\text {th }}$ century. and determining the factors that influenced their formation. The value of intelligence - in the light of the concept of M. Holubets on the political situation of the Hetmanate of the XVIII ${ }^{\text {th }}$ century.

Key words: M. Holubets, the history of the Hetmanate, autonomous rights, the Small Russian Collegium.

\begin{abstract}
Аннотация
В статье рассмотрены взгляды украинского историка Н. Голубиа относительно политического положения Гетманшины XVIII в.; обозначены вопросы, связанные с деятельностью политических институтов на украинских просторах, взаимоотношениями украинских гетманов с представителями российского иаризма. Исследование базируется на принципах историзма, научной объективности, сочиального подхода и причинности. Оно опирается на описательный, аналитико-синтетический и историко-генетический методы. Результатом исследовательской научной работы является характеристика политического развития Гетманщины в течение XVIII в. через призму взглядов Н. Голубия, обоснование обстоятельств, которые стали катализатором для формирования его концепции освещееия исторической «картины» того времени.

Результаты разыскания могут пригодиться начинающим ученым во время исследования отдельных аспектов политической истории Гетманщины XVIII в., в течение преподавания спеикурсов, посвященных событиям, происходившим в Украине в пределах 17091764 г2. Перспективы дальнейтего исследования проблемы заключаются в привлечении более иирокого круга трудов историков, научно-исследовательская деятельность которых проходила на территории Западной Украины в первой половине ХХ в., сравнении их взглядов на события в истории Гетманщины XVIII в. и определении факторов, повлиявших на их формирование. Ценность разыскания - в освещении конщепџии М. Голубца относительно политического положения Гетманщины ХVIII в.
\end{abstract}

Ключевые слова: Н. Голубец, история Гетманщины, автономные права, Малороссийская коллегия. 


\section{ДЖЕРЕЛА ТА ЛІТЕРАТУРА}

1. Герасимова Г. Голубець Микола. Українські історики ХХ століття: біографічний довідник. Київ: Ін-т історії України НАН України. 2004. Вип. 2. Ч. 2. С. 109-110.

2. Гнатів Я. Кам'яна Господиня, або дитячі роки Миколи Голубця. Гнатів Я. Кам'яна Господиня. Львів: Місіонер, 2001. С. 13-52.

3. Головацький І. Дещо про Миколу Голубця. Літопис Червоної Калини: істориколітературний часопис. 1998. № 16/18 (82/84). С. 380-385.

4. Голубець М. Велика історія України. URL: http://irbis-nbuv.gov.ua/ulib/item/ UKR0001144

5. Качкан В. А. 3 етнокультурного поля Миколи Голубця. Украӥнська періодика: історія і сучасність: доп. та повід. третьої Всеукр. наук.-теор. конф. 22-23 грудня 1994 р. Львів, 1995. С. 214-217.

6. Качкан В. А. Українське народознавство в іменах: навч. посіб. у 2-х ч. Київ: Либідь, 1995. Ч. 2. 288 с.

7. Кічура Л. Ідея державності в публіцистиці Миколи Голубця (за матеріалами преси). URL: file:///C:/Users/\%D0\%9B\%D1\%8E\%D0\%B4\%D0\%BC\%D0\%B8\%D0\% BB\%D0\%B0/Downloads/5187-10228-1-PB.pdf.

8. Савицький Р. Микола Голубець: стисла бібліографія. Мистецькі сmудіi. 1993. Чис. 2/3. С. 70-74.

9. Сварник І. Голубець Микола. Довідник з історії Украӥни (A-Я). 2-ге вид., доопр. і доп. Київ: Генеза, 2002. С. 169.

10. Сварник I. Українська шляхта в дослідженнях Миколи Голубця. Генеалогічні записки Украӥнського геральдичного товариства. Біла Церква, 2000. Вип. 1. С. 47-49.

11. Стефанишин Т. Художня критика Миколи Голубця у контексті мистецького процесу Львова 1920-1930-х рр. Вісник Львівської академії мистецтв: зб. наук. працьь. Львів: ЛАМ, 2004. Вип. 14. С. 222-236.

\section{References}

1. Gerasimova, G. Golubec' Mikola. (2004). Ukraïns'ki istoriki HH stolittya: biografichnij dovidnik [The Ukrainian historians of the twentieth century: a biographical dictionary]. Kiïv: In-t istoriï Ukraïni NAN Ukraïni.

2. Gnativ, Ya. (2001). Kam'yana Gospodinya, abo dityachi roki Mikoli Golubcya. Gnativ Ya. Kam'yana Gospodinya [Stone the Hostess, or Mykola Holubets's childhood]. L'viv: Misioner.

3. Golovac'kij, I. (1998). Deshcho pro Mikolu Golubcya [Something about Mykola Holubets]. Litopis Chervonoï Kalini: istoriko-literaturnij chasopis, 16/18 (82/84), 380-385.

4. Golubec', M. (1993). Velika istoriya Ukraïni [The Great history of Ukraine]. URL: http://irbis-nbuv.gov.ua/ulib/item/UKR0001144

5. Kachkan, V. A. (1994). Z etnokul'turnogo polya Mikoli Golubcya [From the ethnocultural fields of Mykola Holubets]. Ukraïns'ka periodika: istoriya i suchasnist': dop. ta povid. tret'oï Vseukr. nauk.-teor. konf., 214-217. 
6. Kachkan, V. A. (1995). Ukraïns'ke narodoznavstvo v imenah [Ukrainian ethnology in names (Ch. 2)]. Kiïv: Libid'.

7. Kichura, L. Ideya derzhavnosti v publicistici Mikoli Golubcya (za materialami presi) [The idea of nationhood in the journalistic writings of Mykola Holubets (press release)]. URL: file:///C:/Users/\%D0\%9B\%D1\%8E\%D0\%B4\%D0\%BC\%D0\%B8\% D0\%BB\%D0\%B0/Downloads/5187-10228-1-PB.pdf

8. Savic'kij, R. (1993). Mikola Golubec': stisla bibliografiya [Mykola Holubets: concise bibliography]. Mistec'ki studiï, 2/3, 70-74.

9. Svarnik, I. (2002). Golubec' Mikola [Mykola Holubets]. Dovidnik z istoriï Ukraïni (A-Ya). Kiïv: Гeneza.

10. Svarnik, I. (2000). Ukraïns'ka shlyahta v doslidzhennyah Mikoli Golubcya [Ukrainian gentry in the research of Mykola Holubets]. Genealogichni zapiski Ukraïns'kogo geral'dichnogo tovaristva, 1, 47-49.

11. Stefanishin, T. (2004). Hudozhnya kritika Mikoli Golubcya u konteksti mistec'kogo procesu L'vova 1920-1930-h rr. [Art criticism of Mykola Holubets in the context of the artistic process of Lviv 1920-1930-ies.]. Visnik L'vivivs'koï akademiï mistectv: zb. nauk. prac', 14, 222-236.

УДК $930(19 / 20)$

\section{ПОЛЬСЬКЕ ЗЕМЛЕВОЛОДІННЯ ПРАВОБЕРЕЖНОЇ УКРАЇНИ У ПРАЦЯХ ДОРЕВОЛЮЦІЙНИХ ДОСЛІДНИКІВ}

\section{Стоберська Надія}

Статтю присвячено аналізу праць дореволючійного періоду з проблеми польського землеволодіння в губерніях Правобережної України. Входження регіону до складу Російської імперії змінило становище польських землевласників, що сприяло зростанню зацікавленості дослідників дореволюиійної доби до його історії та тогочасного стану. Доробок авторів того покоління становить інтерес, оскільки вони досліджували сучасне їм явище. Метою цього дослідження є аналіз праць, створених у другій половині XIX-на початку XX cm., з проблеми польського землеволодіння в украӥнських губерніях. Стаття спирається на приниипи наукової об 'єктивності та історизму, у процесі ї̈ написання застосовані аналітико-синтетичний, статистичний, історико-типологічний методи. Основу розвідки склали праці дореволючійних авторів, серед яких переважають історики та економісти.

Висвітлено погляди дослідників другої половини XIX-початку XX cm. на походження, становище, еволюцію польського землеволодіння. Показано, щчо дореволюиійні дослідники акцентували увагу на дворянсько-поміщицькому господарстві Росії, тоді як польське згадувалося лише в його контексті, зокрема в частині законодавчого забезпечення обмеження польського впливу та зменшення їхнього землеволодіння. Характерною особливістю дореволючійних досліджень стало те, щуо в них зосереджений великий масив статистичного матеріалу щьоо землеволодіння Правобережної України.

Ключові слова: польське землеволодіння, Правобережна Україна, дореволючійні дослідники, історіографія. 